\title{
Floral Diversity of Common Flora in Kolleru Lake A.P
}

\author{
Brahmaji Rao .P, Vijayalakshmi B.B R.G. \\ Department Of Environmental Science, Acharya Nagarjuna University, Guntur-522510. Andhra Pradesh, India
}

\begin{abstract}
Kolleru lake is the largest fresh water lake in India. It is situated partly in Krishna and partly in West Godavari districts of Andhra Pradesh. The present study is aimed to reveal the biodiversity especially common flora of Kolleru lake with the following objectives 1.To identify the diversity of common Flora present in the study area. 2.Quantification of common flora at arena and aquatic flora in Kolleru lake studied separately based on selected field stations.. The investigation carried out for a period of about 12 months from February 2010 to 2011 at 17 selected locations. Lake supports a rich variety of Macrophytes, some of which harbour diverse groups of organisms often in prodigious proportions. Present work highlights the study common flora of Kolleru Lake and nature of water quality depends on presence of diversity of common flora at different field stations in kolleru area. Frequencies, Relative frequency, Abundance, Relative abundance were calculated. The three characteristics were computerised for all the species falling in all transects using IVI formula. The Each species status in each field station was described high frequency and less frequency by calculating the relative frequency value. The observations were variant among field stations, the species diversity and their status was changed both in common flora and aquatic flora. Systematic position of common flora in Kolleru lake was tabulated. Species wise distribution of common flora \& dominance of the species were calculated in different field stations. Dominance of the species varied in particular to the field station. Tridax procumbens was commonly found in 14 field stations which is dominant based on the IVI value among the field stations. MIV was calculated for common flora to know the role of each species in the plant community. MIV value is higher at Chatakaya station consisting 6 species having nearly 60 frequency percentage of each species. Studies conclude floral diversity and distribution pattern of a plant community. Single species wise status, Dominance, IVI and MIV was established based on the percent frequency of all species in the field stations of study area.
\end{abstract}

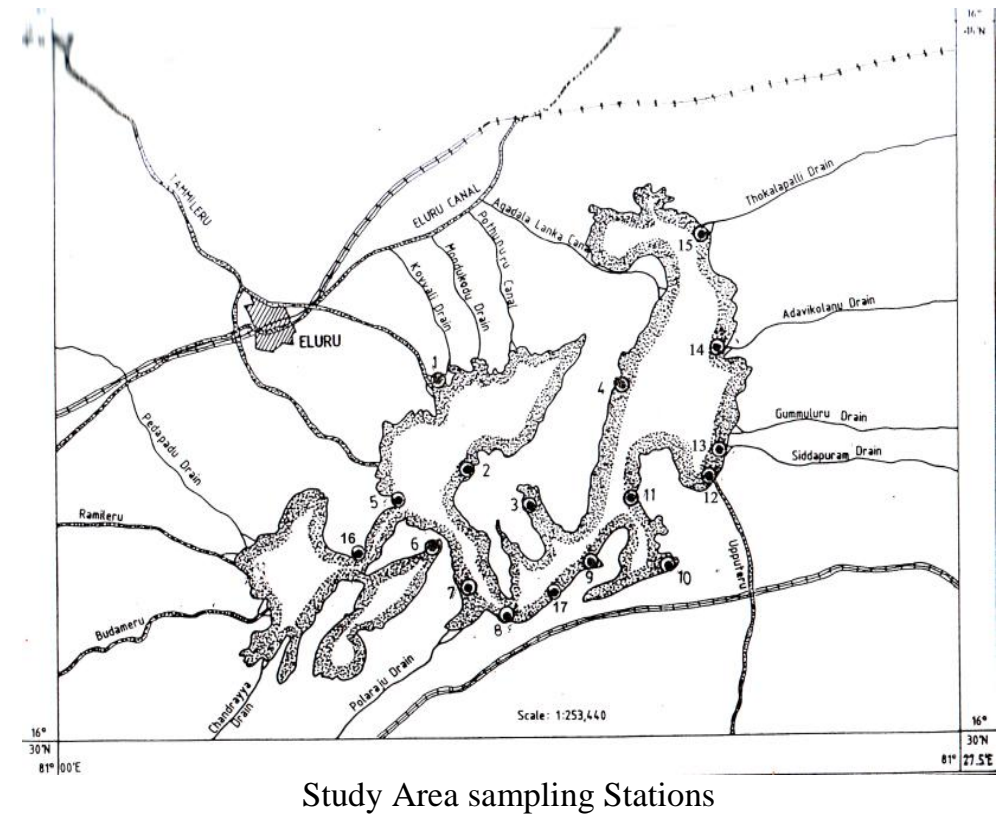

\section{Introduction}

Kolleru lake is the largest natural fresh water lake in India. It is situated partly in Krishna and partly in West Godavari districts of Andhra Pradesh. The lake (Long $81^{\circ}-40^{\prime}$ to $80^{\circ}-20^{\prime}$ East, Lat $17^{0}-25^{\prime}$ to $16^{0}-$ $28^{\prime}$ north) has an area of $954 \mathrm{Sq}$. Kms. At 3 MSL to +10 MSL. 17 Field stations were selected based on geographical distribution of water bodies known as bed and belt villages among the kolleru lake. Station wise flora was described in kolleru lake. 


\section{Methodology}

The present investigation carried out for a period of about 12 months, physico-chemical and biological examination of water and weeds in the lake was undertaken from February 2010 to January 2011 at 17 selected locations. Altogether 32 Flora were divided into 17 aquatic flora and 15 common flora were collected and identified. During the present investigation, as attempt was made to study the common flora of the lake and analysed vegetation.

Vegetation Analysis

Frequency: Frequency as introduced by Raunkiaer (1934) indicates the number of sampling units in which a species occurs (Mishra, 1968). Frequency of common flora and aquatic flora of kolluru lake refers to the degree of dispersion of individual species in an area, and is usually expressed in terms of percentage of occurrence. Frequency and relative frequency of species in the study area are measured by using the formulae of Curtis (1933) which are given below:

Number of occurrence of a species

$$
\text { Frequency = -------------- x } 100
$$

No. of occurrences of particular species

Relative Frequency $=\frac{\text { No. of occurrences of particular species }}{\text { Total number of occurrences of all the species }}$

The values of relative frequency are calibrated on a 10-point scale to assign a status to the species in each region. Four distinct groups are derived from this 10-point scale and each group in each region is designated as follows:

$$
\begin{array}{rll}
>25 & = & \text { Very Frequent } \\
15-24 & = & \text { Frequent } \\
5-14 & = & \text { Less Frequent } \\
<5 & = & \text { Rare }
\end{array}
$$

Abundance: The abundance and density represents the numerical strength of species in the community (Mishra, 1968). Abundance is described as the number of individuals per sampling unit of occurrence and density as the number of individuals per sampling units. Abundance and density were calculated using the following formulae:

Total number of site samples taken

Abundance $(\mathrm{A})=$

Number of sampling units of occurrence

Relative Abundance $=$ - $\begin{gathered}\text { Abundance of a particular species } \\ \text { Sum of the abundance of all species }\end{gathered}$

Total number of individuals of a species in all quadrats

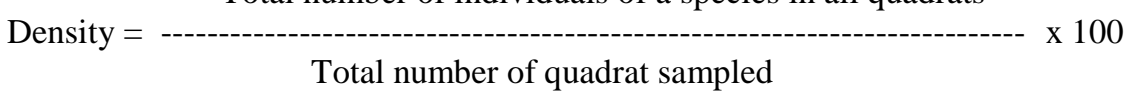

Relative density $=\frac{\text { Density of a particular species }}{\text { Sum of the densities of all species }}$

\section{Importance Value Index (IVI)}

The concept of 'Important Value Index (IVI)' has been developed for expressing the dominance and ecological success of any species, with a single value (Mishra, 1968). This index utilises three characteristics, viz., relative frequency, relative density, and relative abundance. The three characteristics were computerised using frequency, density and abundance for all the species falling in all transects using following formulae. 
$\mathrm{IVI}=$ Relative frequency + Relative abundance + Relative density

Maturity Index Value (MIV), Similarity Index (SI), Co-efficient Difference (CD) and Diversity Index (DI) are used to assess, the Maturity, Similarity, Diversity of vegetation among various field stations (Philips, 1959).

\section{Maturity Index Value (MIV)}

The degree of maturity of a plant community is established based on the percent frequency of all species in the sites of study regions and divided by the number of species occurrence. This is Maturity Index Value. Sampling is done on the basis of 5 quadrats at each site and the frequency of each species is calculated, before calculating the percentage frequency. The Maturity Index Values (MIV) are compared among different stations and it is inferred that the one nearer to 100 is highly matured in the community over others as suggested by Pichi-Sermolli (1948).

$$
\mathrm{MIV}=\frac{\text { Frequency of all species }}{\text { Number of species studied }}
$$

In the past, a number of investigations were carried out on the biology and ecology of Kolleru lake depending on the objectives and immediate necessities.

\section{Results \& Discussion}

The observations were varied among field stations, the species diversity and their status was calculated in common flora

MONDUKODU; First field station consist 12 species in the arena, the maximum IVI 35.00, the highest MIV 100 was observed in Tridax procumbens. The minimum MIV 20 was observed in Calotropis gigantea, Croton bonplandianum. The minimum IVI is observed in Calotropis gigantea, Croton bonplandianum (6.88). The highest relative frequency was exhibited by Tridax procumbens (25). The lowest value was shown by Calotropis gigantea and Croton bonplandianum (3.0).

Second field station is GUDIWAKA LANKA, observed 8 species in the arena, the maximum IVI 29.49 and highest MIV 60 were observed in Cassia occidentalis and the minimum IVI was observed in Calotropis gigantea (13.08) and the lowest MIV 40 was noticed in the remaining species of arena of this station. The highest relative frequency was exhibited by Cassia occidentales (19) and the lowest was exhibited by Calotropis gigantea (8).

Third field station is PRATHIKOLLA LANKA is having 7 species among highest IVI value (30) was observed in case of Cassia occidentalis. The lowest value 12.94 was noticed with Croton bonplandianum. The highest relative frequency 18.0 was observed in Aerva lanata, Sida acuta, Calotropis gigantea and Cassia occidentalis. The lowest value 6 was observed in case of Croton bonplandianum. The highest MIV value 60 was observed in Aerva lanta, Sida acuta, Calotropis gigantea and the lowest 20 was observed in Croton bonplandianum.

CHETTUNNAPADU is the fourth station; In the 7 species of arena, the highest IVI value of 26.67 and highest relative frequency 17 were noticed with Abutilon indicum, Coccinia indica, Leucas aspera. The lowest IVI value 14.78, the lowest relative frequency 9, lowest MIV 40 were observed in the case of Calotropis gigantea. The highest MIV 60 was noticed in Achyranthes aspera, Abutilon indicum, Acalypha indica, Coccinia indica, leucas aspera and Phyllanthus maderaspatensis.

The fifth selected location is PEDAYADLAGADI; Of the 7 species in the arena, the highest IVI value (29.21) was observed with Tridax procumbens and Cassia occidentalis. The lowest value 16.19 was observed with Sida acuta and Leucas aspera. The highest relative frequency 19 was observed in case of Tridax procumbens, Aerva lanata and Cassia occidentalis, the lowest IVI value 10 was observed in case of Acalypha indica, Sida acuta and Leucas aspera. The highest MIV 80 was observed in Aerva lanata and the lowest MIV 20 was noticed in Acalypha indica.

KOVVADALANKA is the sixth field station, Among the 6 species of arena, the maximum IVI value 42.59, and the highest relative frequency (28) were observed in the case of Cassia occidentalis. The lowest IVI value 18.89, and the lowest relative frequency 11 were observed in the case of Acalypha indica and Tephrosia purpurea. The highest MIV 60 was observed in Tridax procumbens, Aerva lanata, Boerhavia difussa, Cassia occidentalis and Phyllanthus maderaspatensis. The lowest MIV 20 was observed in Croton bonplandianum. Hence cassia occidentalis is dominant.

The Seventh field station is DEVICHINTAPADU; in the arena identified 4 species, among Achyranthes aspera is dominant with the maximum IVI value 61.33, highest relative frequency 40.00 and highest MIV 60. The lowest IVI value (22.0), lowest relative frequency 10.00 and lowest MIV 20 were observed in Abutilon indicum. 
VEGILAMALLI is the eighth field station; Of the 6 species in the arena, the maximum IVI value was observed in Croton bonplandianum - 33.33. The minimum value was observed in the case of Phyllanthus maderaspatensis (14.78), and the same species has the lowest relative frequency 9, the highest relative frequency 22 was observed in Croton bonplandianum. The highest MIV 60 was observed in Aerva lanata, Acalypha indica, Sida acuta and Croton bonplandianum. The lowest MIV 40 was observed in Tridax procumbens, Coccinia indica and Phyllanthus maderaspatensis.

The ninth field station is CHATAKAYA. Of the 6 species in the arena, Tridax procumbens is dominant having the maximum IVI value of 33.33 and the minimum value 20 was exhibited by Acalypha indica and Leucas aspera. The highest relative frequency of 22 was exhibited by Tridax procumbens and phyllanthus maderaspatensis. The lowest value 13 was observed in the case of Acalypha indica, Croton banplandianum and Leucas aspera, the highest MIV 100 was observed in Phyllanthus maderaspatensis and the lowest (40) was observed in Croton bonplandianum.

BHUJABALAPATNAM was the tenth field station; Of the 6 species in the arena, Croton bonplandianum exhibited a maximum IVI value of 40.48. The minimum IVI value 16.19 , lowest relative frequency (10) were observed in Phyllanthus maderaspatensis. The highest relative frequency of 24 was observed in Croton bonplandianum. The highest MIV 80 was observed in Coccinia indica and the lowest 40 was observed in Aerva lanata, Croton bonplandianum and Phyllanthus maderaspatensis.

KOLLETIKOTA was the eleventh field station; Of the 6 species in the arena, the maximum IVI value 38.33 was observed in Cocinia indica. The minimum IVI value 14.17 and minimum relative frequency (8) were observed in Sida acuta. The maximum relative frequency of 25.0 was observed in Coccinia indica. The minimum MIV 20 was exhibited by Centella asiatica. The maximum MIV 60 was observed in Tridax procumbems, Coccinia indica, Boerhavia diffusa and Cassia occidentalis.

UPPUTERU BRIDGE was the twelfth station. Of the 4 species in the arena, the maximum IVI value was shown by Phyllanthus maderaspatensis (65.71). The minimum IVI value 24.29 , minimum relative frequency 14 were shown by Tephrosia purpurea. The maximum relative frequency 43, highest MIV 60 were exhibited by Acalypha indica and Phyllanthus maderaspatensis. The minimum MIV 40 was noticed in Achyranthes aspera and Tephrosia purpurea.

SIDDHAPURAM is the thirteenth station; Of the 7 species in the arena, the maximum IVI value 37.69 , highest relative frequency 27.1 were exhibited by Phyllanthus maderaspatensis. The minimum IVI value 13.08, the lowest relative frequency 8 were exhibited by Abutilon indicum and Calotropis gigantea. The highest MIV 100 was observed in Acalypha indica and Phyllanthus maderaspatensis. The lowest MIV 40 was shown by Tridax procumbens, Abutilon indicum and Calotropis gigantea.

ADAVIKOLANU is the fourteenth field station. Of the 6 species in the arena, Sida acuta is dominant having the maximum IVI value 38.33 and the highest relative frequency 25.0. The minimum IVI Value was shown by Croton bonplandiamum (14.17), and also lowest relative frequency 8, lowest MIV 40. The highest MIV 60 was observed in Tridax procumbens, Aerva lanata, Sida acuta, Tephrosia Purpurea and Coccinia indica.

THOKALAPALLI is the fifteenth Station; Of the 5 species in the arena, the maximum IVI was exhibited by Tridax procumbens (41.82). The Minimum IVI was shown by other species Aerva lanata, Acalypha indica, Coccinia indica and Phyllanthus maderaspatensis (27.88). The same relative frequency (18) was exhibited by all species Aerva lanata, Acalypha indica, Coccinia indica, Phyllanthus maderaspatensis, Acalypha indica except Tridax procumbens (27.0). The same MIV 60 was noticed by all species Tridax procumbens, Aerva lanata, Acalypha indica, Coccinia indica, Phyllanthus maderaspatensis and Acalypha indica.

CHINAYADLAGADI is the sixteenth station; Of 9 species in the arena, Achyranthes aspera is dominant having the maximum IVI 29.85, the highest relative frequency 21 . The minimum IVI 10.00 and the lowest relative frequency 6 were shown by Acalypha indica. The maximum MIV 80 was observed in Achyranthes aspera and Abutilon indicum. The minimum MIV 40 was noticed in Acalypha indica, Calotropis gigantea and Cassia occidentalis.

The seventeenth station in ATAPAKA. Of the 8 species in the arena, the maximum IVI (29.85), highest relative frequency (21) was noticed in Leucas aspera and the minimum IVI (6.47), lowest relative frequency (3) were shown by Tephrosia purpurea. The highest MIV 80 was observed in Cassia occidentalis and Leucas aspera. The minimum MIV 20 was noticed in Acalypha indica and Tephrosia purpurea.

The observations were varied among field stations, the species diversity and their status was calculated in common flora. Kolleru Lake was tabulated (Table-1). The distinguished variation among common flora and species wise status based on relative frequency (Table-3) were observed significantly. Species wise distribution of common flora (Table-2) \& dominance of the species were calculated based on IVI value (Table-4) in different field stations (Figure-1). The maturity Index value (Table-5) denotes the degree of maturity of a plant community based on the relative frequency of all species of occurrence. The MIV was calculated for common species among all field stations (Figure-2) to know the role of each species in the plant community. 


\section{Conclusion}

Floral analysis to identify the species status in each field station was described high frequency and less frequency by calculating the relative frequency value. Dominance of the species varied in particular to the field station. Tridax procumbens was commonly found in 14 field stations which is dominant based on the IVI value among the field stations. The remaining species are based on the field station particular species is dominant. Common flora distribution pattern of each species may be varied due several environmental factors. The MIV values of common flora are higher $63 \%$ are observed in the $9^{\text {th }}$ field station Chatakaya consisting 6 species having nearly 60 frequency percentage of each species. and minimum MIV value is 43 at field station (2) Gudiwakalanka consisting 8 species having nearly 40 frequency percentage of each species. . Studies conclude floral diversity and distribution pattern of a plant community. Single species wise status, Dominance, IVI and MIV was established based on the percent frequency of all species in the field stations of study area

\section{References}

[1]. Malini (2010) Kolleru lake revisited: the post 'Operation Kolleru' scenario. Current Science 98(10): 1281-1291

[2]. Nageswara Rao K, K Ch V Naga Kumar, P Subraelu, G Demudu, B Visweswara Reddy and B Hema.

[3]. Raunkiaer,C.1934. The life forms of plants and statistical geography. Claredon, Oxford,pp.632.

[4]. Seshavatharam.V. and Venu. P. 1982. Ecological Studies of the Vegetations

[5]. of Kolleru Lake. Bull. Botanical Survey of India 24(1-4): 70-75.

[6]. Venkateswarlu V (1993) Kolleru Lake Ecosystiem - A comprehensive study in Kolleru Lake Past \& Present.

[7]. Wetland International (2008) Integrated management plan for Kolleru Wildlife Sanctuary, Final Report prepared for the Forest Department. Government of Andhra Pradesh.

[8]. Wildlife Management Division, Eluru (undated) Brief note on Koleru Wildlife Sanctuary, p22

TABLE - 1: Systematic Position Of Common Flora Present In Kolleru Arena

\begin{tabular}{|c|l|l|l|}
\hline S.No. & \multicolumn{1}{|c|}{ Family } & \multicolumn{1}{|c|}{ Name of the species } & \multicolumn{1}{c|}{ Vernacular name } \\
\hline 1 & Asteraceae & Tridax procumbenes & Gaddichamanthi \\
\hline 2 & Amaranthaceae & Aerva lanata & Kondapindi Aku \\
\hline 3 & Amaranthaceae & Achyranthes aspera & Uttareni \\
\hline 4 & Malvaceae & Abutilon indicum & Duvvana Kaya \\
\hline 5 & Euphorbiaceae & Acalypha indica & Muripundi Aku \\
\hline 6 & Malvaceae & Sida acute & Sida \\
\hline 7 & Fabaceae & Tephrosia purpurea & Vampali \\
\hline 8 & Apiaceae & Centella asiatica & Saraswathi Aku \\
\hline 9 & Cucurbitaceae & Coccinia indica & Donda \\
\hline 10 & Nyctaginaceae & Boerhavia diffusa & Boerhavia (Atakamamidi) \\
\hline 11 & Asciepediaceae & Calotropis gigantea & Jilledu \\
\hline 12 & Caesalpinaceae & Cassia occidentalis & Kasintha \\
\hline 13 & Euphorbiaceae & Croton bonplandianum & Galivana \\
\hline 14 & Lamiaceae & Leucas aspera & Tummi \\
\hline 15 & Euphorbiaceae & Phyllanthus maderaspatensis & Nela Usiri \\
\hline
\end{tabular}

TABLE -2: Species-Wise Distribution Pattern Of Common Flora Present Among Field Stations In Kolleru Lake

\begin{tabular}{|c|c|c|c|c|c|c|c|c|c|c|c|c|c|c|c|c|c|c|}
\hline S.No. & $\begin{array}{c}\text { Name of the Plant } \\
\text { Species }\end{array}$ & 1 & 2 & 3 & 4 & 5 & 6 & 7 & 8 & 9 & 10 & $\begin{array}{l}1 \\
1\end{array}$ & 12 & 13 & 14 & 15 & 16 & 17 \\
\hline 1 & Tridax Procumbens & + & + & + & - & + & + & + & + & + & - & + & - & + & + & + & + & + \\
\hline 2 & Aerva lanata & + & - & + & - & + & + & - & + & + & + & - & - & - & + & - & + & - \\
\hline 3 & Achyranthes aspera & - & + & - & + & - & - & + & - & - & + & - & + & + & - & + & + & - \\
\hline 4 & Abutilon indicum & + & - & - & + & - & - & + & - & - & - & - & - & + & - & - & + & - \\
\hline 5 & Acalypha indica & + & + & - & + & + & + & - & + & + & + & - & + & + & - & + & + & + \\
\hline 6 & Sida acuta & + & - & + & - & + & - & - & + & - & - & + & - & - & + & - & + & - \\
\hline 7 & Tephrosia purpurea & - & + & - & - & - & + & - & - & - & - & - & + & - & + & - & - & + \\
\hline 8 & Centella asiatica & - & - & - & - & - & - & - & - & - & - & + & - & - & - & - & - & - \\
\hline 9 & coccinia indica & + & + & + & + & - & - & - & + & - & + & + & - & - & + & + & - & + \\
\hline 10 & Boerhavia diffusa & + & - & - & - & - & + & - & - & - & - & + & - & - & - & - & - & - \\
\hline 11 & Calotropis gigantea & + & + & + & + & - & - & - & - & - & - & - & - & + & - & - & + & + \\
\hline 12 & Cassia occidentalis & + & + & + & - & + & + & - & - & - & - & + & - & - & - & - & + & + \\
\hline 13 & $\begin{array}{l}\text { Croton } \\
\text { Bonplandianum }\end{array}$ & + & - & + & - & + & - & - & + & + & + & - & - & - & + & - & + & - \\
\hline 14 & Leucas aspera & + & - & - & + & - & - & - & - & + & - & - & - & + & - & - & - & + \\
\hline 15 & $\begin{array}{l}\text { Phyllanthus } \\
\text { maderaspatensis }\end{array}$ & + & + & - & + & + & - & + & - & + & + & - & + & + & - & + & - & + \\
\hline & Total & 12 & 8 & 7 & 7 & 7 & 6 & 4 & 6 & 6 & 6 & 6 & 4 & 7 & 6 & 5 & 9 & 8 \\
\hline
\end{tabular}




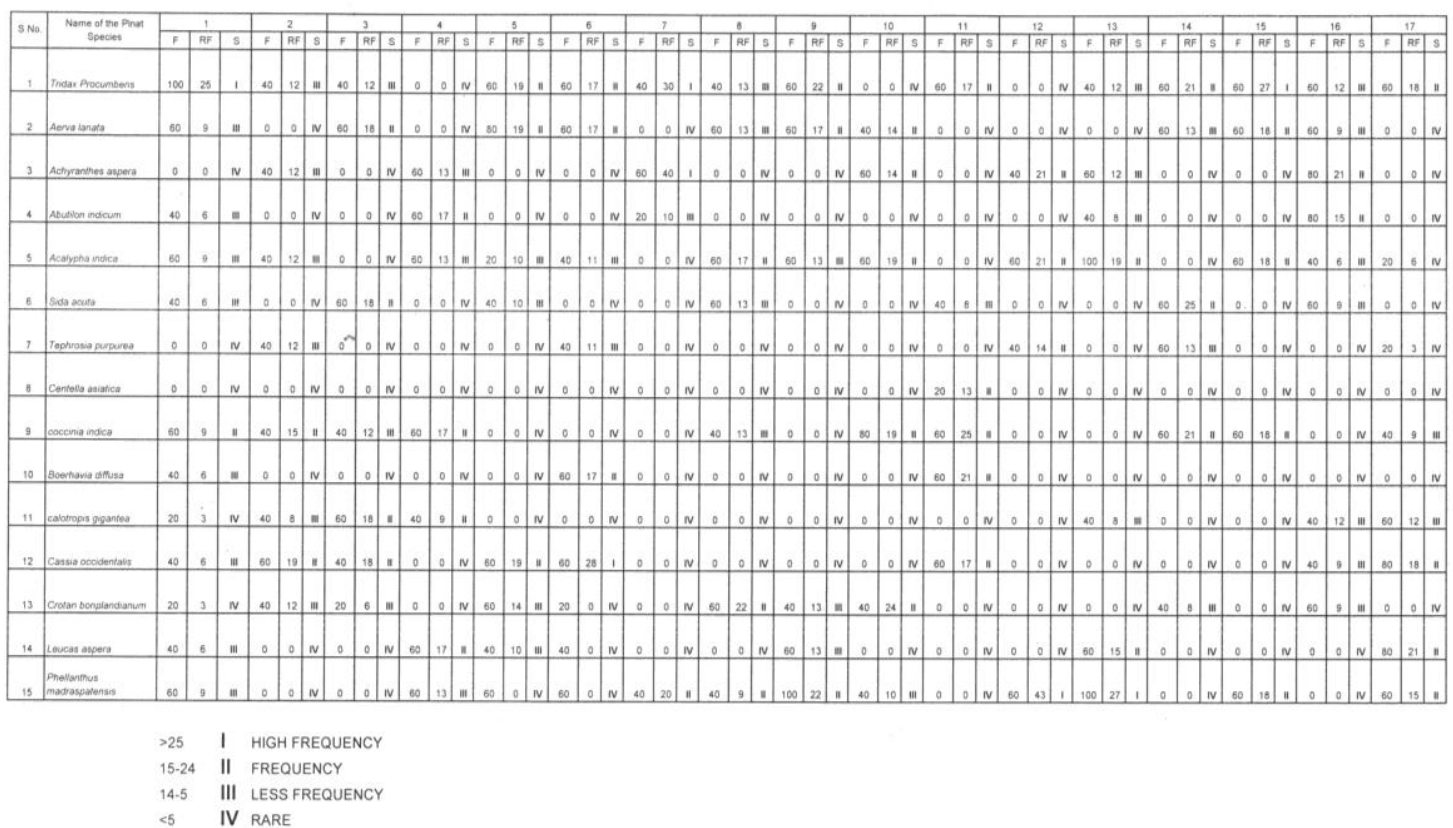

Table- 03: Species-wise status of common flora based on Relative frequency

\begin{tabular}{|c|c|c|c|c|c|c|c|c|c|c|c|c|c|c|c|c|c|c|}
\hline \multirow{2}{*}{ S.No. } & \multirow{2}{*}{$\begin{array}{l}\text { Name of the Pinat } \\
\text { Species }\end{array}$} & \multicolumn{17}{|c|}{ IVI VALUES IN DIFERENT FIELD STATIONS } \\
\hline & & 1 & 2 & 3 & 4 & 5 & 6 & 7 & 8 & 9 & 10 & 11 & 12 & 13 & 14 & 15 & 16 & 17 \\
\hline 1 & Tridax Procumbens & 35.00 & 19.62 & 20.00 & 0.00 & 29.21 & 25.56 & 51.00 & 22.17 & 33.33 & 0.00 & 25.56 & 0.00 & 19.62 & 31.94 & 41.82 & 18.04 & 27.06 \\
\hline 2 & Aerva lanata & 14.38 & 0.00 & 27.06 & 0.00 & 27.62 & 25.56 & 0.00 & 20.00 & 26.67 & 24.29 & 0.00 & 0.00 & 0.00 & 19.17 & 27.88 & 13.53 & 0.00 \\
\hline 3 & Achyranthes aspera & 0.00 & 19.62 & 0.00 & 20.00 & 0.00 & 0.00 & 61.33 & 0.00 & 0.00 & 21.90 & 0.00 & 36.43 & 17.69 & 0.00 & 0.00 & 29.85 & 0.00 \\
\hline 4 & Abutilon indicum & 10.63 & 0.00 & 0.00 & 26.67 & 0.00 & 0.00 & 22.00 & 0.00 & 0.00 & 0.00 & 0.00 & 0.00 & 13.08 & 0.00 & 0.00 & 21.32 & 0.00 \\
\hline 5 & Acalypha indica & 14.38 & 19.62 & 0.00 & 20.00 & 20.95 & 18.89 & 0.00 & 26.67 & 20.00 & 29.21 & 0.00 & 32.86 & 26.92 & 0.00 & 27.88 & 10.00 & 12.94 \\
\hline 6 & Sida acuta & 10.63 & 0.00 & 27.06 & 0.00 & 16.19 & 0.00 & 0.00 & 20.00 & 0.00 & 0.00 & 14.17 & 0.00 & 0.00 & 38.33 & 0.00 & 13.53 & 0.00 \\
\hline 7 & Tephrosia purpurea & 0.00 & 19.62 & 0.00 & 0.00 & 0.00 & 18.89 & 0.00 & 0.00 & 0.00 & 0.00 & 0.00 & 24.29 & 0.00 & 19.17 & 0.00 & 0.00 & 6.47 \\
\hline 8 & Centella asiatica & 0.00 & 0.00 & 0.00 & 0.00 & 0.00 & 0.00 & 0.00 & 0.00 & 0.00 & 0.00 & 27.50 & 0.00 & 0.00 & 0.00 & 0.00 & 0.00 & 0.00 \\
\hline 9 & coccinia indica & 14.38 & 26.15 & 20.00 & 26.67 & 0.00 & 0.00 & 0.00 & 22.17 & 0.00 & 27.62 & 38.33 & 0.00 & 0.00 & 31.94 & 27.88 & 0.00 & 15.00 \\
\hline 10 & Boerhavia diffusa & 10.63 & 0.00 & 0.00 & 0.00 & 0.00 & 25.56 & 0.00 & 0.00 & 0.00 & 0.00 & 31.94 & 0.00 & 0.00 & 0.00 & 0.00 & 0.00 & 0.00 \\
\hline 11 & calotropis gigantea & 6.88 & 13.08 & 27.06 & 14.78 & 0.00 & 0.00 & 0.00 & 0.00 & 0.00 & 0.00 & 0.00 & 0.00 & 13.08 & 0.00 & 0.00 & 20.00 & 18.04 \\
\hline 12 & Cassia occidentalis & 10.63 & 29.49 & 30.00 & 0.00 & 29.21 & 42.59 & 0.00 & 0.00 & 0.00 & 0.00 & 2556 & 0.00 & 0.00 & 0.00 & 0.00 & 15.00 & 25.59 \\
\hline 13 & Crotan bonplandianum & 6.88 & 19.62 & 12.94 & 0.00 & 21.90 & 0.00 & 0.00 & 33.33 & 22.17 & 40.48 & 0.00 & 0.00 & 0.00 & 14.17 & 0.00 & 13.53 & 0.00 \\
\hline 14 & Leucas aspera & 10.63 & 0.00 & 0.00 & 26.67 & 16.19 & 0.00 & 0.00 & 0.00 & 20.00 & 0.00 & 0.00 & 0.00 & 23.59 & 0.00 & 0.00 & 0.00 & 29.85 \\
\hline 15 & Phellanthus madraspatensis & 14.38 & 0.00 & 0.00 & 20.00 & 0.00 & 0.00 & 34.00 & 14.78 & 30.43 & 16.19 & 0.00 & 65.71 & 37.69 & 0.00 & 27.88 & 0.00 & 22.55 \\
\hline & Total & 159.4 & 166.8 & 164.1 & 154.8 & 161.3 & 157.0 & 168.3 & 159.1 & 152.6 & 159.7 & 163.1 & 159.3 & 151.7] & 154.7 & 153.3 & 154.8 & 157.5 \\
\hline
\end{tabular}

Table 04-IVI values in different field stations 


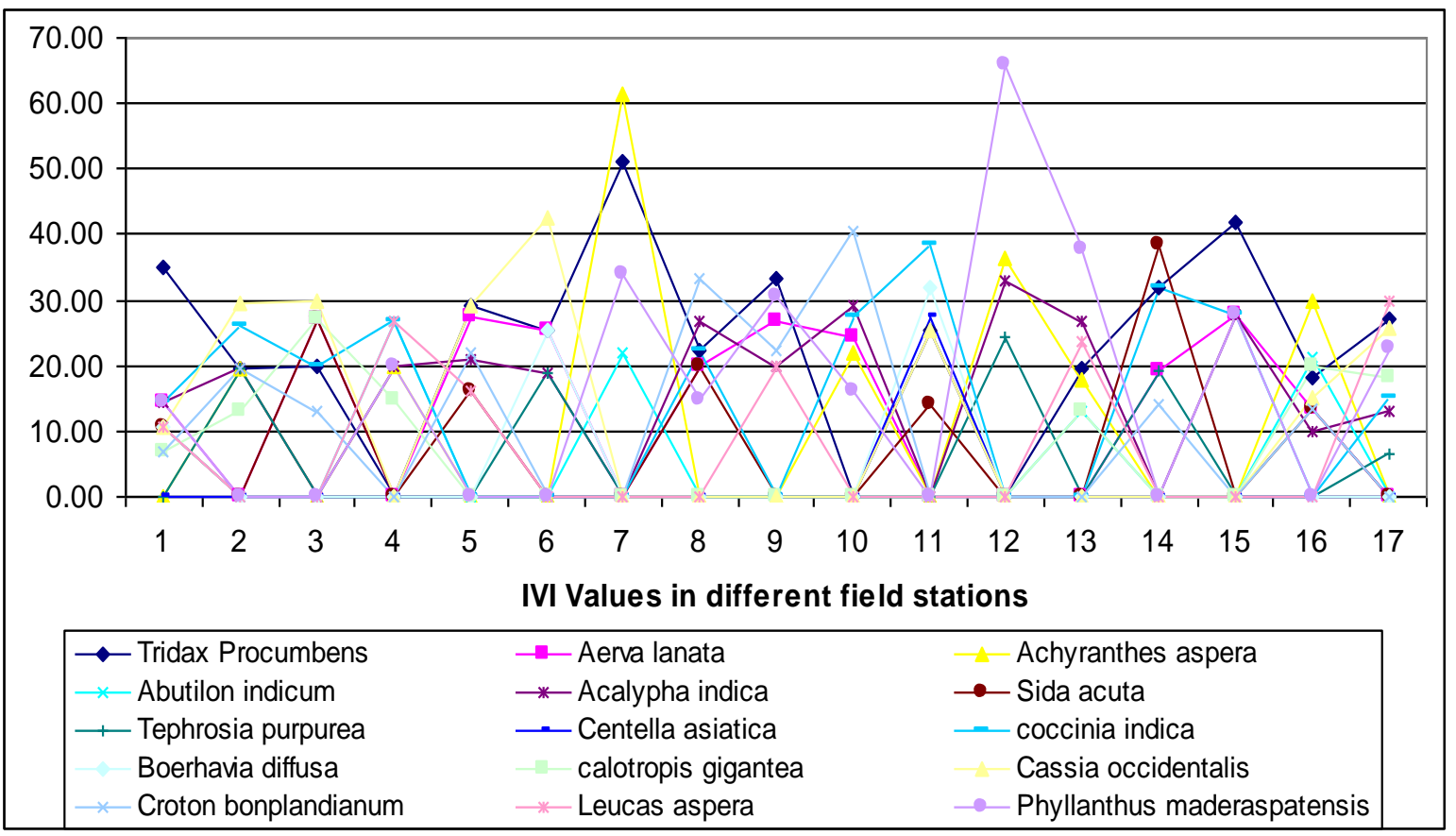

FIGURE-1; IVI values in different field stations of common flora

TABLE -05: Maturity Index Values (Miv) Of Common Flora Present Among Field Stations At Kolleru Arena

\begin{tabular}{|c|c|c|c|c|c|c|c|c|c|c|c|c|c|c|c|c|c|c|}
\hline \multirow{2}{*}{$\begin{array}{l}\text { SI } \\
\text { No. }\end{array}$} & \multirow[t]{2}{*}{ Plant Species } & \multicolumn{17}{|c|}{ FREQUENCY \% } \\
\hline & & 1 & 2 & 3 & 4 & 5 & 6 & 7 & 8 & 9 & 10 & 11 & 12 & 13 & 14 & 15 & 16 & 17 \\
\hline 1 & Tridax Procumbens & 100 & 40 & 40 & 0 & 60 & 60 & 40 & 40 & 60 & 0 & 60 & 0 & 40 & 60 & 60 & 60 & 60 \\
\hline 2 & Aerva lanata & 60 & 0 & 60 & 0 & 80 & 60 & 0 & 60 & 60 & 40 & 0 & 0 & 0 & 60 & 60 & 60 & 0 \\
\hline 3 & Achyranthes aspera & 0 & 40 & 0 & 60 & 0 & 0 & 60 & 0 & 0 & 60 & 0 & 40 & 60 & 0 & 0 & 80 & 0 \\
\hline 4 & Abutilon indicum & 40 & 0 & 0 & 60 & 0 & 0 & 20 & 0 & 0 & 0 & 0 & 0 & 40 & 0 & 0 & 80 & 0 \\
\hline 5 & Acalypha indica & 60 & 40 & 0 & 60 & 20 & 40 & 0 & 60 & 60 & 60 & 0 & 60 & 100 & 0 & 60 & 40 & 20 \\
\hline 6 & Sida acuta & 40 & 0 & 60 & 0 & 40 & 0 & 0 & 60 & 0 & 0 & 40 & 0 & 0 & 60 & 0 & 60 & 0 \\
\hline 7 & Tephrosia purpurea & 0 & 40 & 0 & 0 & 0 & 40 & 0 & 0 & 0 & 0 & 0 & 40 & 0 & 60 & 0 & 0 & 20 \\
\hline 8 & Centella asiatica & 0 & 0 & 0 & 0 & 0 & 0 & 0 & 0 & 0 & 0 & 20 & 0 & 0 & 0 & 0 & 0 & 0 \\
\hline 9 & coccinia indica & 60 & 40 & 40 & 60 & 0 & 0 & 0 & 40 & 0 & 80 & 60 & 0 & 0 & 60 & 60 & 0 & 40 \\
\hline 10 & Boerhavia diffusa & 40 & 0 & 0 & 0 & 0 & 60 & 0 & 0 & 0 & 0 & 60 & 0 & 0 & 0 & 0 & 0 & 0 \\
\hline 11 & calotropis gigantea & 20 & 40 & 60 & 40 & 0 & 0 & 0 & 0 & 0 & 0 & 0 & 0 & 40 & 0 & 0 & 40 & 60 \\
\hline 12 & Cassia occidentalis & 40 & 60 & 40 & 0 & 60 & 60 & 0 & 0 & 0 & 0 & 60 & 0 & 0 & 0 & 0 & 40 & 80 \\
\hline 13 & Croton bonplandianum & 20 & 40 & 20 & 0 & 60 & 20 & 0 & 60 & 40 & 40 & 0 & 0 & 0 & 40 & 0 & 60 & 0 \\
\hline 14 & Leucas aspera & 40 & 0 & 0 & 60 & 40 & 40 & 0 & 0 & 60 & 0 & 0 & 0 & 60 & 0 & 0 & 0 & 80 \\
\hline \multirow[t]{3}{*}{15} & $\begin{array}{l}\text { Phyllanthus } \\
\text { maderaspatensis }\end{array}$ & 60 & 0 & 0 & 60 & 60 & 60 & 40 & 40 & 100 & 40 & 0 & 60 & 100 & 0 & 60 & 0 & 60 \\
\hline & Total & 580 & $\begin{array}{r}34 \\
0\end{array}$ & $\begin{array}{r}32 \\
0\end{array}$ & $\begin{array}{r}40 \\
0\end{array}$ & $\begin{array}{r}42 \\
0\end{array}$ & $\begin{array}{r}44 \\
0\end{array}$ & $\begin{array}{r}16 \\
0\end{array}$ & $\begin{array}{r}36 \\
0\end{array}$ & 380 & $\begin{array}{r}32 \\
0\end{array}$ & $\begin{array}{r}30 \\
0\end{array}$ & $\begin{array}{r}20 \\
0\end{array}$ & 440 & $\begin{array}{r}34 \\
0\end{array}$ & $\begin{array}{r}30 \\
0\end{array}$ & $\begin{array}{r}52 \\
0\end{array}$ & $\begin{array}{r}42 \\
0\end{array}$ \\
\hline & MIV & 48 & 43 & 46 & 57 & 53 & 49 & 53 & 51 & 63 & 53 & 50 & 50 & 63 & 57 & 60 & 58 & 53 \\
\hline
\end{tabular}

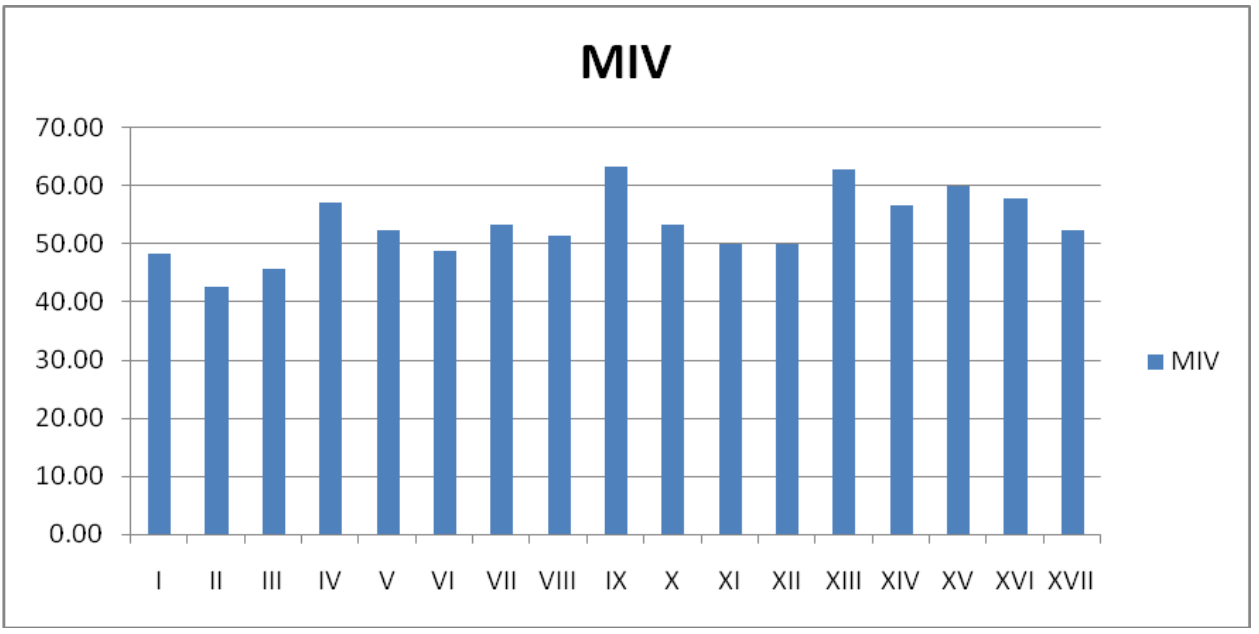

FIGURE-2; Maturity Index Values of common flora present among field stations in Kolleru arena 


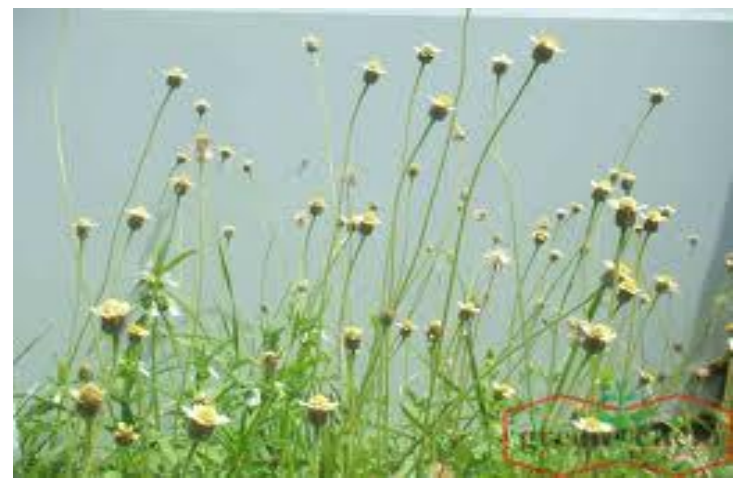

Tridax procumbens

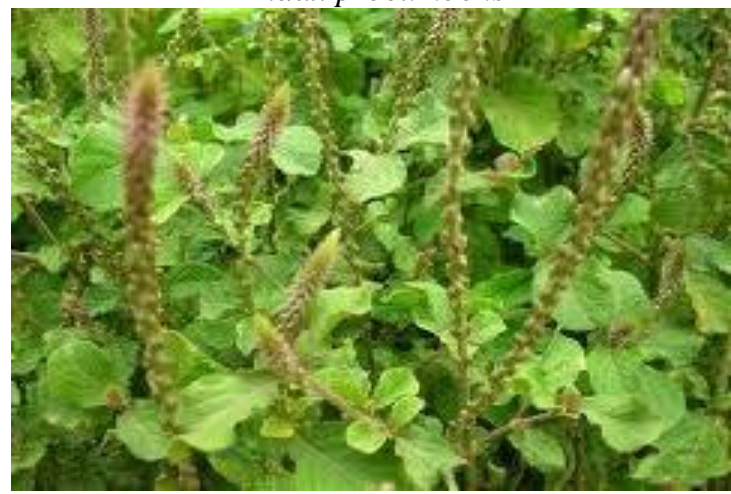

Achyranthes asper

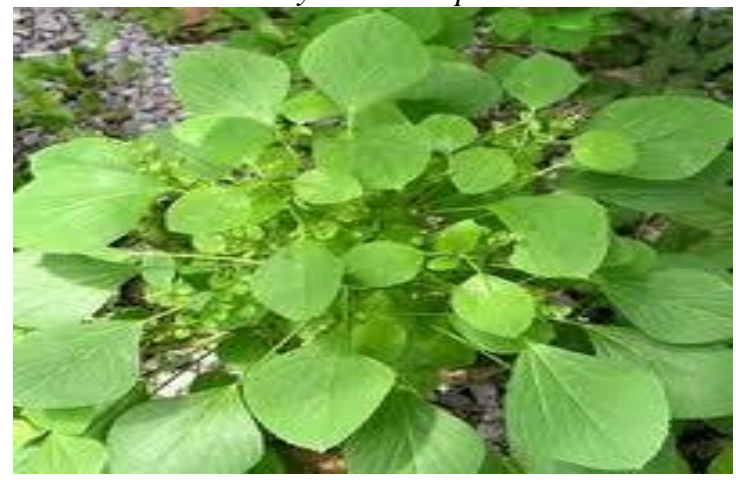

Acalypha indica

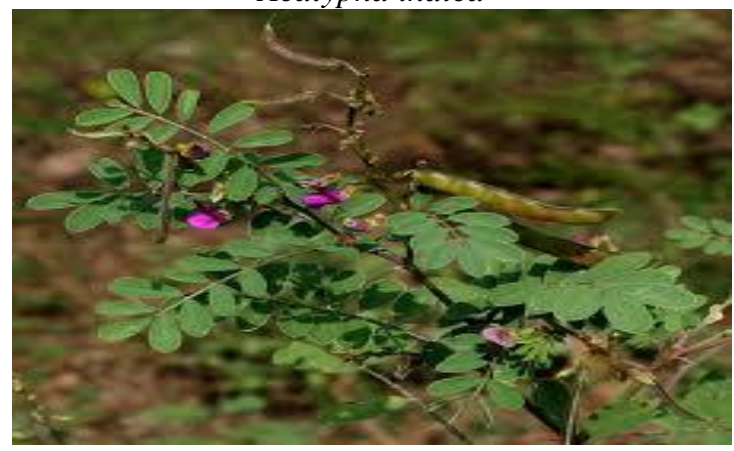

Tephrosia purpurea

Plate 1. Common Flora Present At Kolleru Arena 


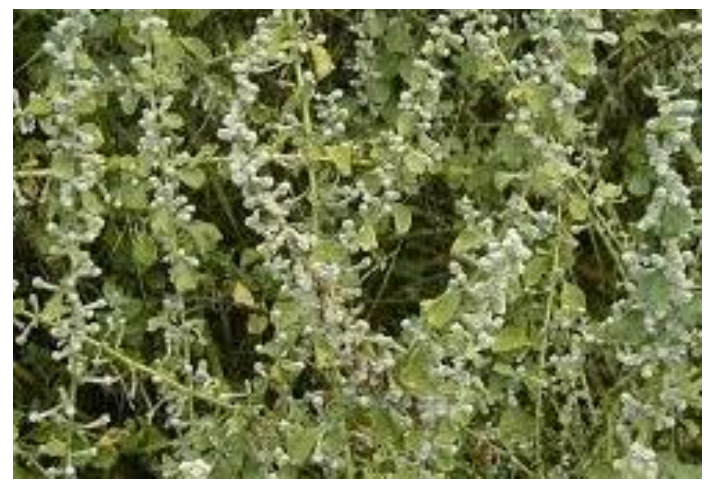

Aerva lanata

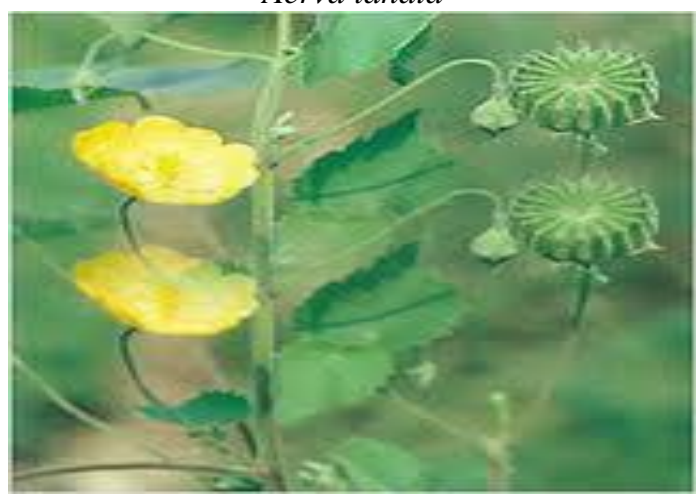

Abutilon indicum

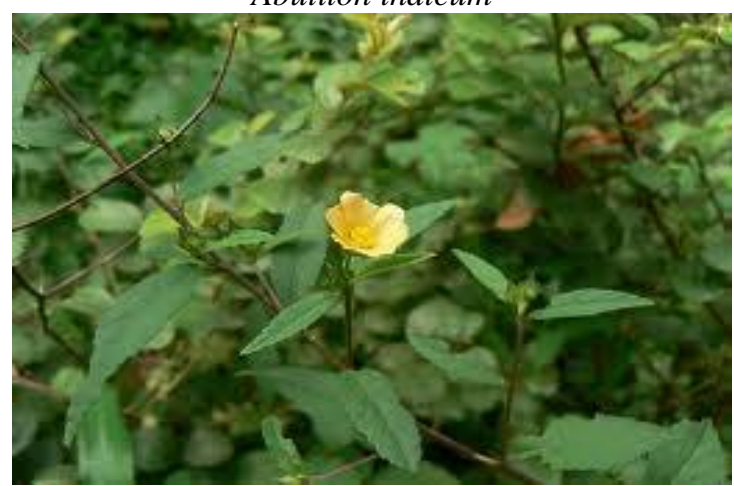

Sida acuta

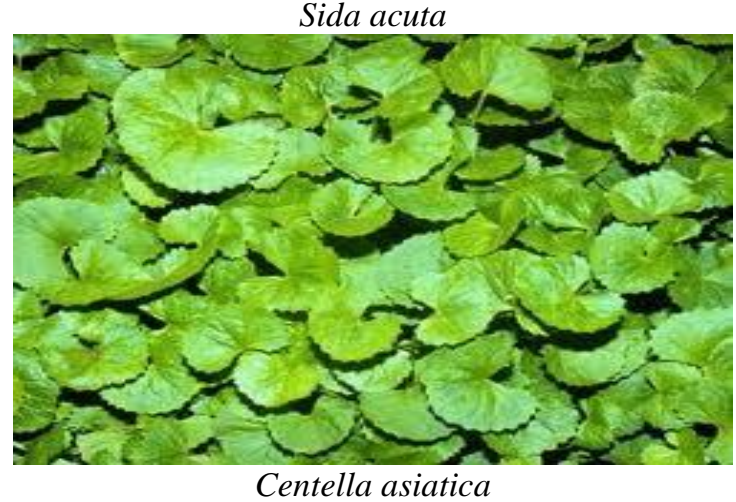

Centella asiatica 


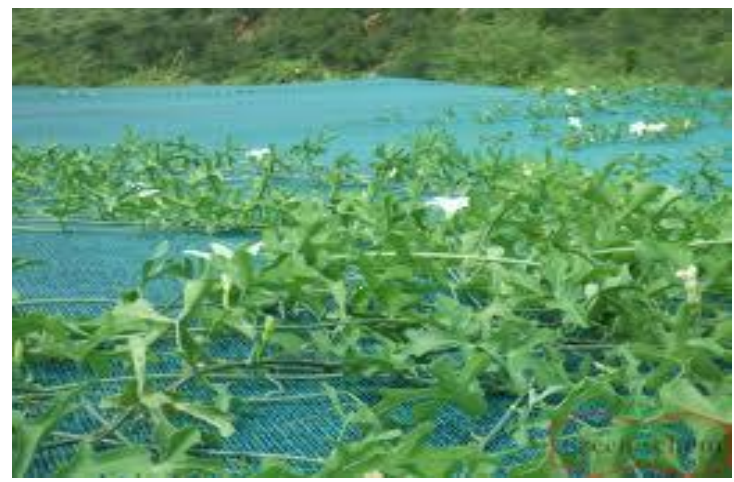

Coccinia indica

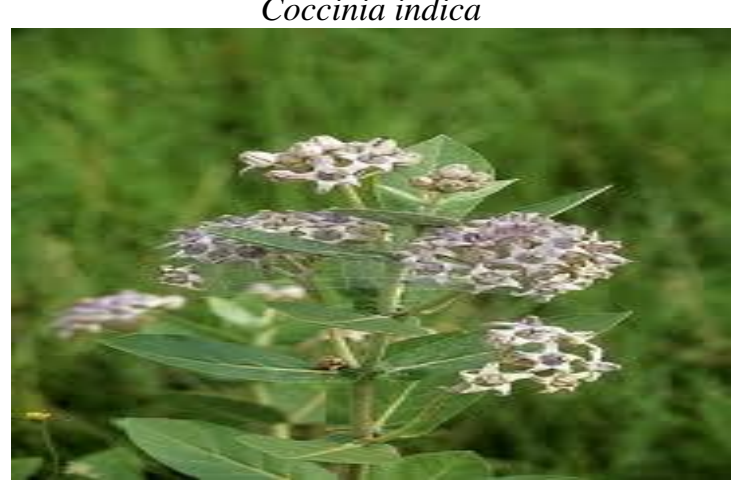

Calotropis gigantea

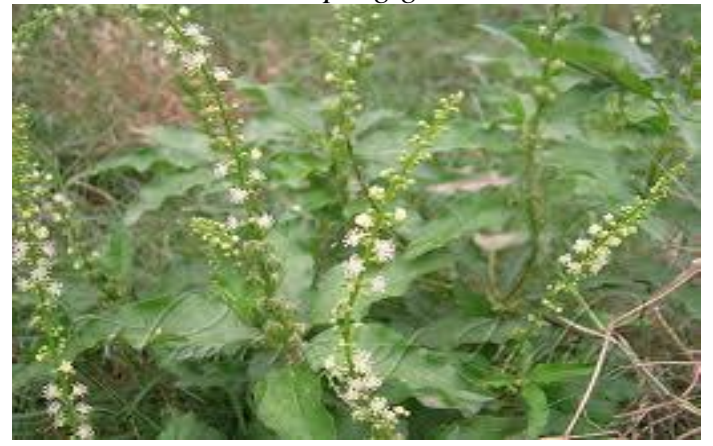

Croton bonplandianum

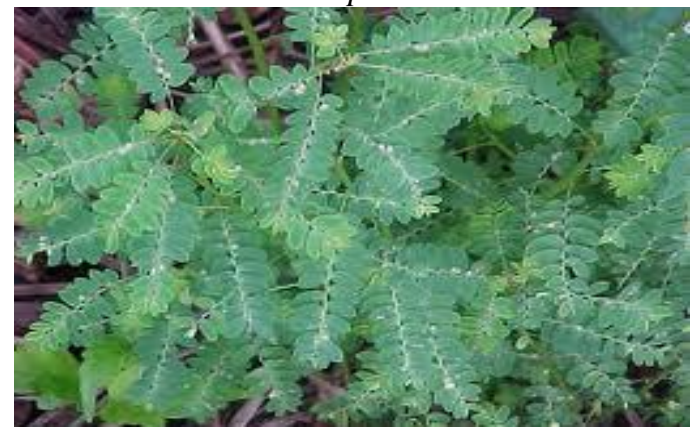

Phyllanthus maderaspatensis

Plate 2. Common Flora Present At Kolleru Arena 


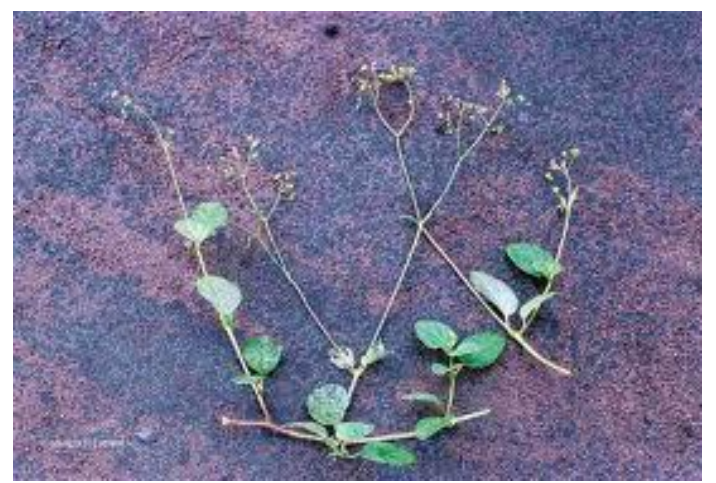

Boerhavia diffusa

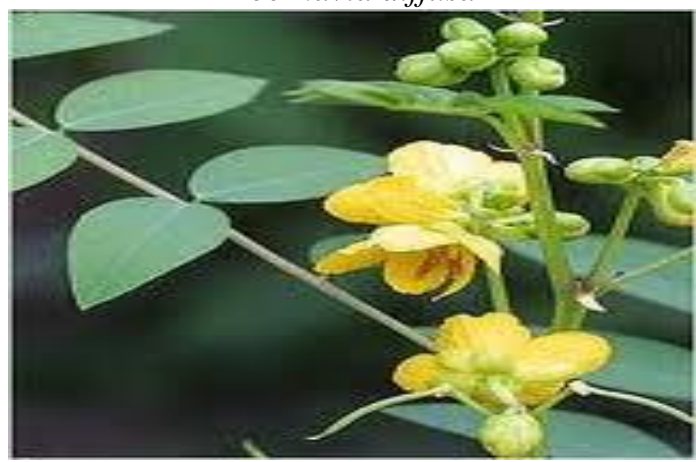

Cassia occidentalis

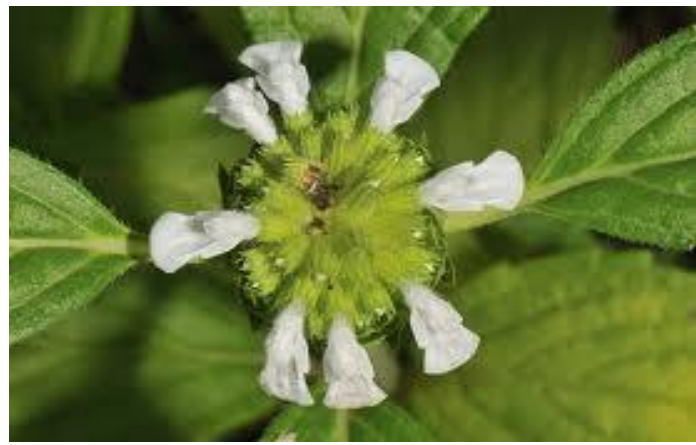

Leucas aspera 